Mr Dragan Simić,

pukovnik, dipl. inž.

Vazduhoplovnotehnicka uprava

GS VJ,

Beograd

\section{SISTEM INTEGRISANOG UPRAVLJANJA ELEKTROMEHANIČKIM SISTEMIMA AVIONA}

UDC: $621.38: 623.746 .3$

Rezime:

Integracija avionskih sistema $i$ podsistema, radi poboljšanja njihovih performansi $i$ smanjenja broja elektro-elektronskih kutija, uz smanjenje njihovih dimenzija i masa, stalni je zadatak projektanata savremenih borbenih vazduhoplova. Veliki broj medusobno zavisnih elektromehanickih sistema aviona $i$ veliki broj elektricnih (relejnih) kutija, posredstvom kojih je izvedeno upravljanje elektromehanickim sistemima, nametali su potrebu njihove integracije. $U$ ovom clanku dat je kratak opis sistema integrisanog upravljanja elektromehanickim sistemima aviona (Utility Systems Management), razvijenog za potrebe savremenog evropskog borbenog aviona EFA (European Fighter Aircraft).

Ključne reči: integracija, arhitektura, upravljanje, elektromehanicki sistemi, motor, gorivo, hidraulika, magistrala podataka, ulazno-izlazni signali.

\title{
SYSTEM OF INTEGRATED MANAGEMENT OF ELECTROMECHANICAL AIRCRAFT SYSTEMS
}

\begin{abstract}
Summary:
One of regular tasks of moder fighter designers is the integration of on-board systems and subsystems aiming to improve their perfomanses as well as to reduce the number of electro-electronic boxes by reducing their dimensions and weights. The integration was necessary due to a large number of mutually dependent electromechanical systems and a large number of electric (relay) boxes for their management. This paper gives a brief description of a system for integrated management of electromechanical aircraft systems (named Utility Systems Management), developed for the European Fighter Aircraft (EFA).
\end{abstract}

Key words: integration, architecture, management, electromechanical systems, engine, fuel, hidraulics, data stream, input-output signals.

\section{Uvod}

Pod pojmom elektromehanickih sistema borbenih aviona podrazumevaju se svi avionski (Utility - korisnički) sistemi namenjeni za kontinualan i pouzdan rad aviona (motor, gorivo, hidraulika, kiseonik, presurizacija, klimatizacija, stajni trap, izvori napajanja, osvetljenja, signalizacije, itd.). Izvan ovih sistema postoje samo sistemi koji su odgovorni za izvrక̌enje borbenih zadataka (misija). $\mathrm{Na}$ svim prethodnim generacijama avio$\mathrm{na}, \mathrm{i}$ velikom broju današnjih borbenih aviona, upravljanje izvršnim mehaničkim i elektromehanickim delovima ovih sistema realizovano je posredstvom električnih (relejnih) kutija. Međutim, stalno prisutni zahtevi za povećanjem performansi i preciznosti upravljanja i poboljša- 
nje kontrole $\mathrm{i}$ detekcije grešaka nametali su potrebu da se i u ove sisteme uvede sve moćnija i preciznija elektronika.

U periodu nakon 1970 . godine, kada su traženi naslednici tada korišćenih aviona, postavljeni su zahtevi da novi avioni budu manjih dimenzija, visokih performansi i visokih manevarskih mogućnosti. Radi njihove realizacije bilo je neophodno sto veće smanjenje dimenzija i mase sve opreme, a posebno elektro-elektronske opreme $\mathrm{i}$ instalacije aviona. Postavljeni zahtevi mogli su biti ostvareni samo integracijom postojeće opreme uz Sto veću primenu savremene elektronike. Međutim, u početnom momentu, integracijom svih elektronskih sistema i njihovim povezivanjem sa integrisanim visokosofisticiranim podsistemom prikazivanja, posredstvom serijskih magistrala podataka, nisu bili obuhvaćeni samo elektromehanički sistemi aviona (slika 1). Sa slike 1 može se uočiti da su jedino elektromehanicki sistemi i njihove funkcije upravljanja i dalje zadržali klasični način povezivanja (integracije), sa elektronskim višenamenskim displejima (MFD - Multifunction Display) podsistema prikazivanja. Ovakav način integracije ukazivao je na nesklad između, sa jedne strane, visokointegrisane elektronske opreme misije $i$, sa druge strane, klasiěno integrisanih elektromehaničkih sistema. Imajući u vidu postavljene zahteve da novi avioni budu znatno boljih performansi, pouzdanosti i pogodnosti za održavanje, jasno je da je to sa klasičnom integracijom elektromehanickkih sistema aviona bilo teško ostvarljivo. Takvo stanje iniciralo je razvoj sistema integrisanog upravljanja elektromehaničkim sistemima aviona.

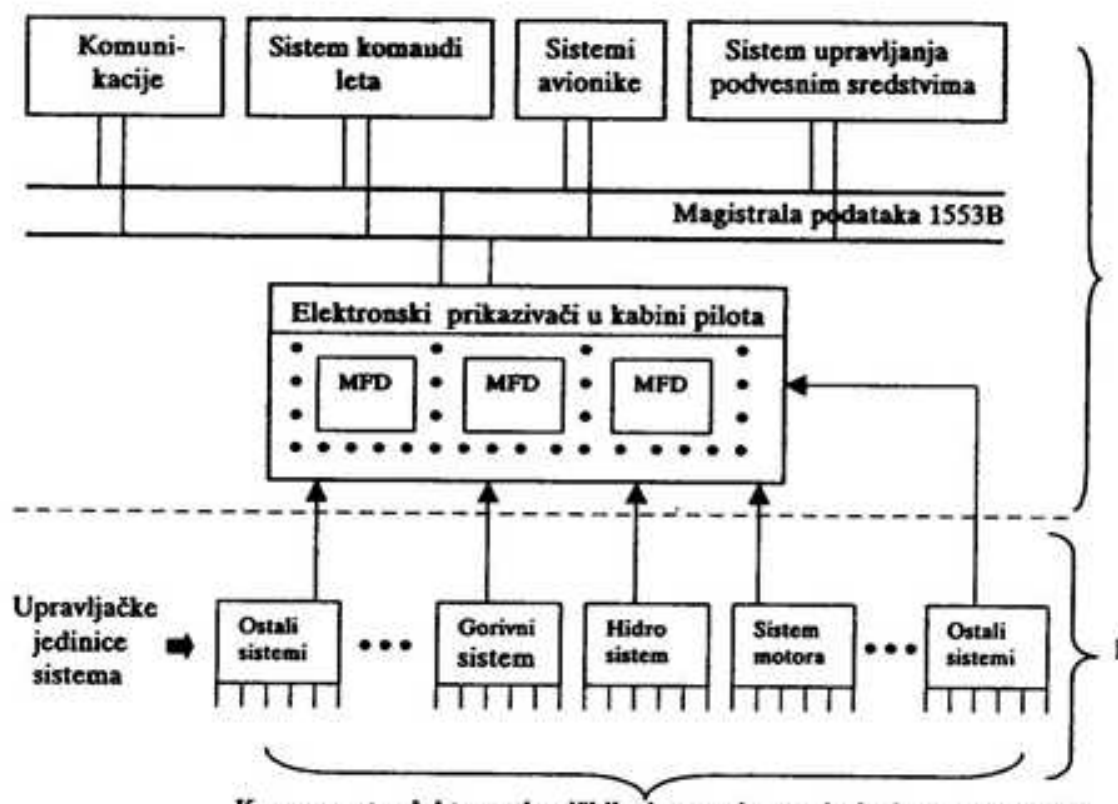

Savremene arhitekture elektronskih sistema aviona

Komponente klasičnib elektromehanickih sistema

Komponente elektromehanickih sistema (senzori, slavine, pumpe itd.)

Sl. I - Početna integracija elektronskih i elektromehaničkih sistema sa elektronskim prikazivačima aviona 


\section{Razvoj sistema integrisanog upravljanja}

Zbog različitog broja i različitih tipova ulazno-izlaznih signala gotovo svaki elektromehanički sistem aviona je specifičan i gotovo unikatan. Pri tome, ovi sistemi ne spadaju u kategoriju sistema obrade informacija (procesnih elektronskih sistema), niti sistema sa visokim integritetom servo-upravljanja, a ni višestruko redundovanih sistema komandi leta. Oni predstavljaju kombinaciju prethodnih sistema, pri cemu svaki od njih ima svoje specifičnosti u pogledu zahtevanog integriteta i pouzdanosti (redundovanosti). Osnovna karakteristika svih ovih sistema je postojanje velikog broja hardverski izvedenih ulaza i izlaza, tj. velikog broja ulaznih (analognih, diskretnih, frekventnih, sinhro, itd.) signala i izlaznih upravljačkih (pogonskih) signala, usmerenih ka raznim izvršnim mehanizmima (uređajima) aviona.

Radi prevazilaženja nesklada između savremene integracije elektronskih sistema i elektronskih prikazivača, sa jedne strane, i klasične integracije elektromehaničkih sistema i elektronskih prikazivača, sa druge strane, pristupilo se istraživanju mogućnosti razvoja sistema integrisanog upravljanja elektromehanickim sistemima aviona. Osnovni cilj istraživanja bio je razvoj univerzalnog $\mathrm{i}$ sveobuhvatnog sistema sa mogućnošću povezivanja preko već standardno korišcenih magistrala podataka 1553B (americki vojni standard MIL-STD-1553B).

Da bi se sagledale slabosti i uvideli nedostaci postojećeg rešenja, analizirano je upravljanje elektromehaničkim sistemima nekoliko, u to vreme, raspoloživih aviona. Istraživanja su pokazala da je pojedinačni (nezavisni) pristup projekto- vanju upravljanja ovim sistemima zahtevao angažovanje velikog broja inženjera različitog stručnog profila. To je rezultiralo odsutnošću potrebnog nivoa projektantske doslednosti, kako u pogledu realizacije sistema, tako i u pogledu njihovog povezivanja sa drugim sistemima i elektronskim prikazivačima. Osim toga, kod pojedinačnog pristupa projektovanju elektromehaničkih sistema sve upravljačke jedinice se specificiraju i realizuju odvojeno, tako da se pojavljuje relativno veliki broj jedinica (uredaja), ciji je rezultat visoka cena sistema.

$\mathrm{Na}$ osnovu sprovedenih istraživanja konstatovano je da većina aviona, sa pojedinačnim rešenjima upravljanja elektromehaničkim sistemima, ima oko 25 do 30 različitih upravljackih uređaja. Takođe, konstatovano je da su gotovo svi ti uređaji uglavnom jednofunkcionalni, tj. da samo jednom i u ograničenom vremenskom intervalu obavljaju svoju funkciju (npr. uređaji za pokretanje motora koriste se samo oko dva minuta u toku jednog leta). Svi ovi uređaji instalirani su u raspoloživi avionski prostor i sa njihovim senzorima, izvršnim mehanizmima i elektronskim prikazivačima povezani posredstvom glomaznih klasičnih konektora i snopova provodnika, osetljivih na elektromagnetna zračenja i uticaje spoljašnjih elektromagnetnih polja.

Shodno uocenim nedostacima postojećeg klasičnog načina upravljanja, istraživana su moguća rešenja integrisanog upravljanja elektromehaničkim sistemima aviona, na način prikazan na slici 2. Pri istraživanju novog rešenja moralo se uzeti u obzir da sistem integrisanog upravljanja treba da zadovolji sledece zahteve:

- da obezbedi upravljanje svih elektromehanickih sistema aviona, kao i njihovu kontrolu (nadzor); 


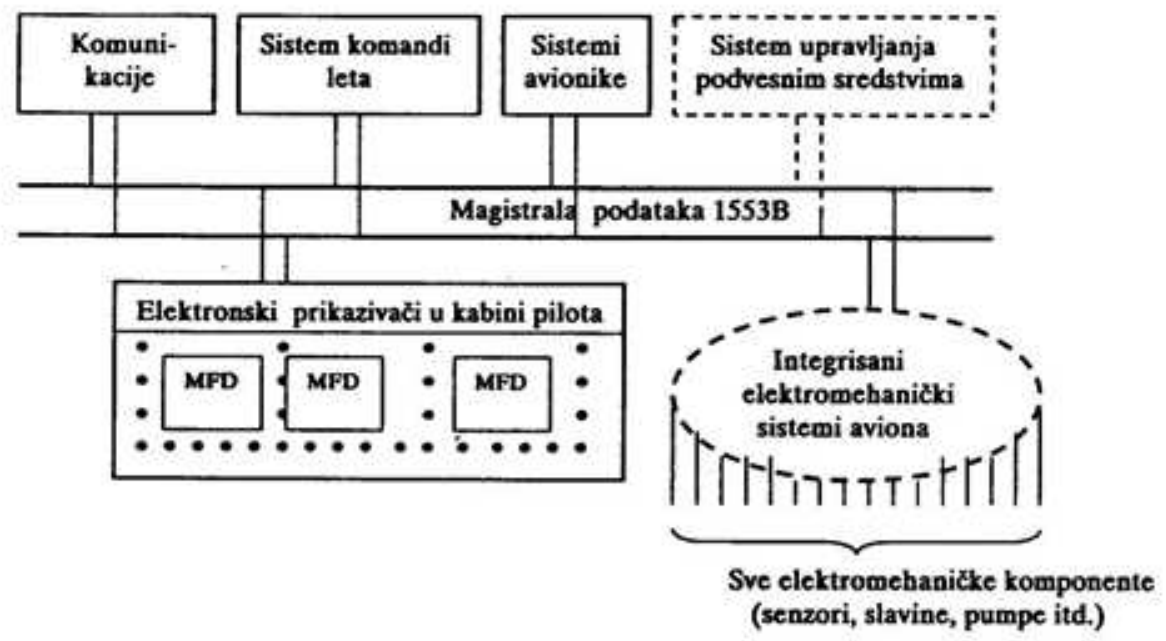

Sl. 2 - Integrisano upravljanje elektromehanickim sistemima aviona

- da obezbedi što veću automatizaciju upravljanja, radi smanjenja opterećenja pilota, ali i zadrži neophodni integritet svakog pojedinačnog sistema;

- da minimizira potrebnu elektriěnu instalaciju i obezbedi odgovarajuci interfejs za povezivanje sa ostalim sistemima aviona, posredstvom serijske magistrale podataka 1553B;

- da minimizira broj potrebnih pojedinačnih uređaja (LRU - Line Replacemenu Units), a samim tim i njihove dimenzije, masu i disipaciju;

- da maksimalno iskoristi sva savremena tehnološka dostignuća kako bi se obezbedila što bolja kontrola specificiranih performansi sistema, t $\mathrm{j}$. njihovo kontinualno testiranje na osnovu ugrađenih testova (BIT - Built In Test).

Istraživanja arhitektura mogućeg reక̌nja integrisanog upravljanja svim elektromehanickim sistemima savremenih borbenih aviona rezultirala su jednom sveobuhvatnom arhitekturom koja je pojednostavljeno prikazana na slici 3 .

Na slici 3 prikazan je savremeni način povezivanja sistema integrisanog uprav- ljanja elektromehaničkim sistemima aviona sa ostalim elektronskim sistemima i upravljačko-prikazivačkim podsistemom aviona. Veze su realizovane posredstvom serijskih magistrala podataka sa vremenskim multipleksiranjem i radom po vojnom standardu $1553 \mathrm{~B}$. Ovako koncipirani i povezani sistem omogućio je da se potrebna avionska instalacija minimizira, broj ulazno-izlaznih signala optimizira, a kontrola upravljanja razmenom informacija posredstvom magistrale podataka poveri kontrolorima magistrale podataka, tj. vrlo moćnim mikroprocesorima implementiranim u, za to određene, avionske računare.

Ključne razlike između sistema konvencionalnog (klasiěnog) i integrisanog upravljanja elektromehaničkim sistemima aviona ilustrovane su na slici 4 .

\section{Eksperimentalni avionski program}

U drugoj polovini devedesetih godina Ministarstvo odbrane Velike Britanije i njihova namenska industrija krenuli 


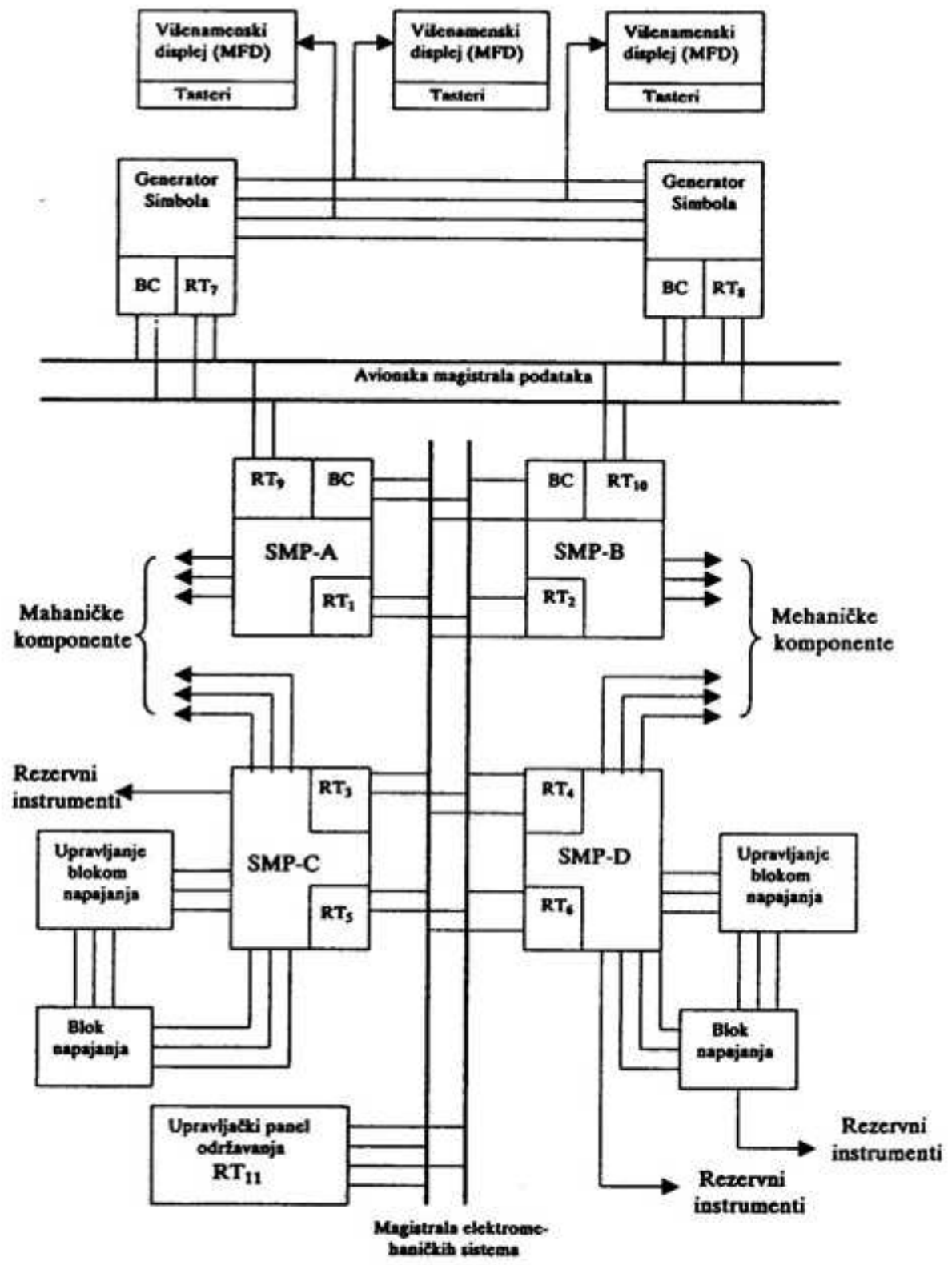

Sl. 3 - Pojednostavljeni prikaz arhitekture integrisanog upravljanja

su u eksperimentalni avionski program za budući evropski borbeni avion (EFA (EAP - Experimental Aircraft Program- - Europen Fighter Aircraft). U okviru me), radi demonstracije mogućnosti, tj. ovog programa sistem integrisanog provere ključnih tehnologija razvijanih upravljanja elektromehaničkim siste- 


\section{Sistem konvencionalnog upravljanja}
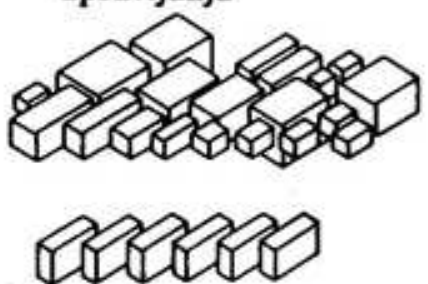

Karakteristike:

- od 20 do 25 posebnih LRU,

- 6 relejnih kutija za generisanje signala upravljanja (pogona),

- jako veliki broj žica, konektora i postolja,

- posebni (pojedinačni) instrumenti ili elektronski paneli.
Sistem integrisanog upravljanja (UMS)

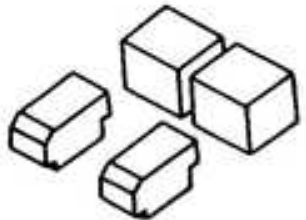

Karakteristike:

- samo 4 posebne LRU,

- moguénost povezivanja preko magistrale podataka $1553 \mathrm{~B}$,

- distribucija prikupljanja $i$ obrade podataka,

- interno realizovano napajanje posebnih LRU,

- interfejs sa savremeno integrisanom kabinom i MFD.

\section{Sl. 4 - Uporedni pregled konvencionalnog $i$ integrisanog sistema}

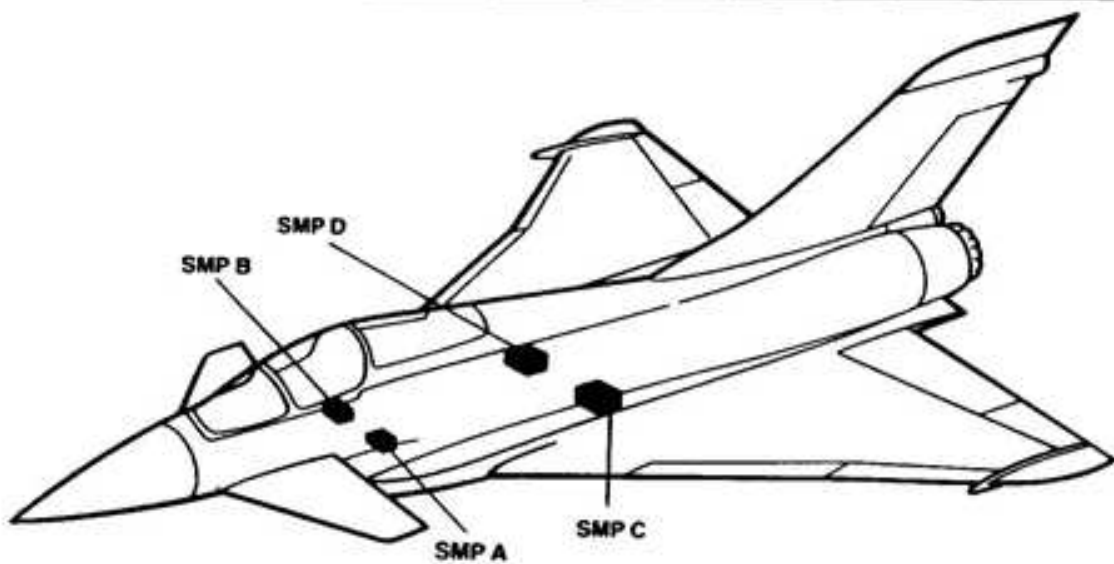

Osnovne grupe funkcija:

- upravljanje motorom i indikacija njegovih stanja,

- upravljanje gorivom i praćenje stanja ostatka i utroška goriva,

- upravljanje hidraulickim sistemom i indikacija njegovih stanja,

- upravljanje sistemom klimatizacije pilotske kabine i regulacijom temperature u istoj,

- upravljanje radom osnovnih i pomoenih (sekundarnih) izvora električnc energije,

- upravljanje radom unutrašnjih i spoljašnjih svetala i signalizacija, grejačima, podešavanjem položaja pilotskog sedišta i sl.

Sl. 5 - Raspored procesora upravljanja elektromehanickim sistemima i funkcije sistema integrisanog upravljanja 
mima aviona pojavio se kao jedna od primarnih oblasti demonstracije visokih tehnologija.

Raspored cetiri, na EFA ugrađene, linijski zamenljive jedinice $\mathrm{i}$ osnovne grupe funkcija realizovane u okviru sistema integrisanog upravljanja elektromehaničkim sistemima, prikazani su na slici 5. Cetiri prikazane jedinice se, u dostupnoj literaturi pojavljuju pod nazivom ,procesori upravljanja elektromehaničkim sistemima" (SMP - Systems Management Processors). Međutim, u sustini to nisu samo procesori upravljanja elektromehaničkim sistemima već dvoprocesorski realizovani računari sa memorijama i velikim brojem interfejsa ula- zno-izlaznih signala. Osim funkcije upravljanja (tj. generisanja izlaznih upravljackkih signala usmerenih ka raznim izvršnim mehanizmima aviona) procesori upravljanja elektromehanickim sistemima obavljaju i funkcije prikupljanja, konverzije i obrade ulaznih signala, kao i napajanja električnom energijom svih njihovih modula.

\section{Opis sistema}

Blok-Šema sistema integrisanog upravljanja elektromehaničkim sistemima aviona, razvijenog za potrebe eksperimentalnog avionskog programa (EAP), prikazana je na slici 6. Procesori

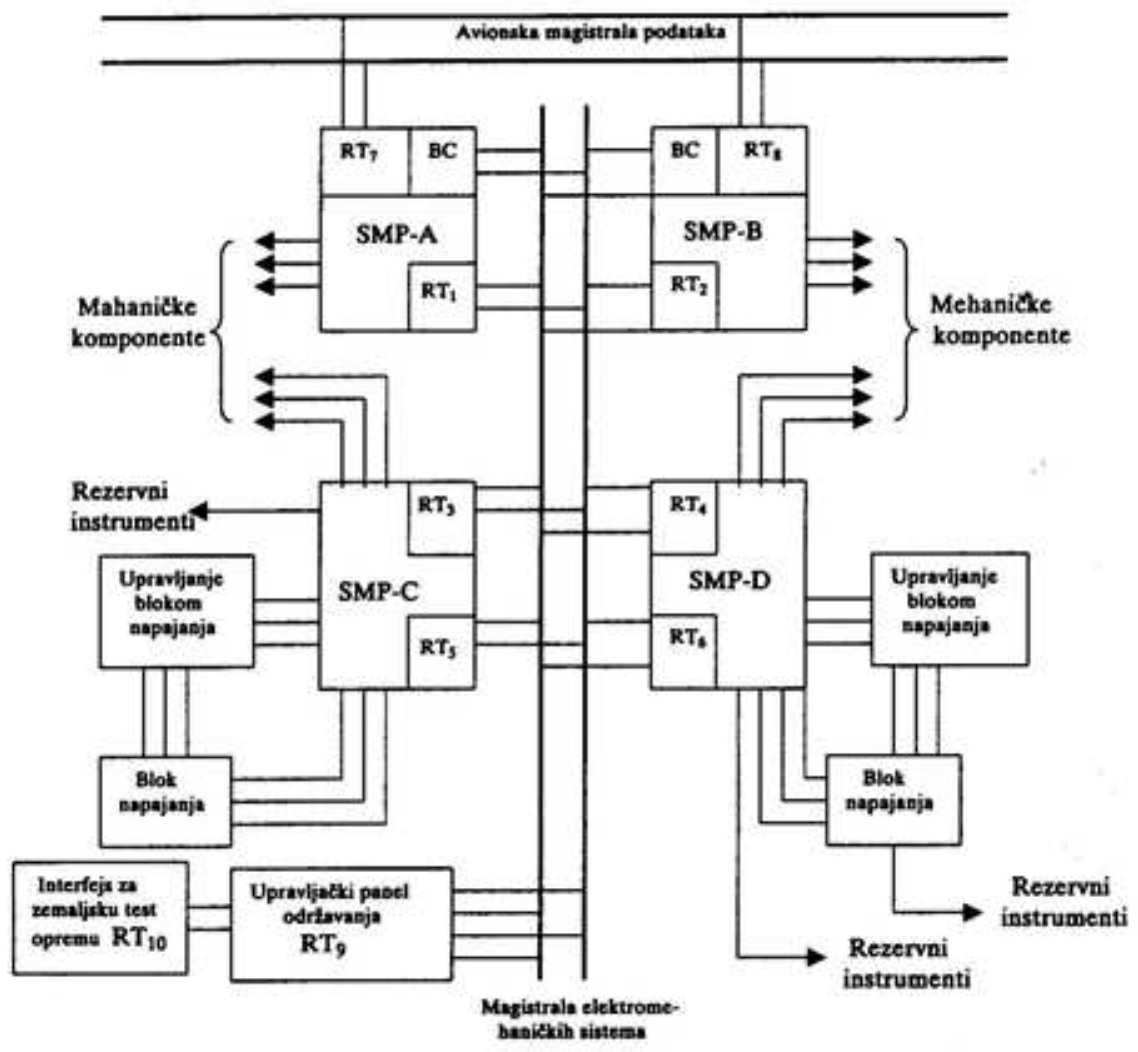

Sl. 6 - Arhitektura sistema integrisanog upravljanja za eksperimentalni avionski program $(E A P)$ 
upravljanja elektromehaničkim sistemima (SMP-A, B, C i D) međusobno su povezani posredstvom redundovane (dvostruke) serijske magistrale podataka elektromehaničkih sistema. Glavni i rezervni kontroler magistrala (BC-Bus Controlor) podataka locirani su u SMP-A i SMP-B. Preko interfejsa SMP-A i SMP$-B, t j$. udaljenih terminala $\mathrm{RT}_{7} \mathrm{i} \mathrm{RT}_{8}(\mathrm{RT}$ - Remote Terminal) sistem je povezan na avionsku magistralu podataka, na koju se povezuju svi ostali elektronski sistemi aviona (komunikacijski, navigacijski, upravljanja letom, upravljanja podvesnim sredstvima, upravljanja i prikazivanja u pilotskoj kabini, itd.). Radi obezbeđenja potrebnog nivoa pouzdanosti prenosa, preko magistrale elektromehaničkih sistema, veze procesorskih modula i magistrala su redundovane (duplirane), tj. procesorski modul SMP-A je povezan preko $\mathrm{BC}$ i $\mathrm{RT}_{1}$, modul SMP-B preko $\mathrm{BC}$ i $\mathrm{RT}_{2}$, modul SMP-C preko $\mathrm{RT}_{3} \mathrm{i}$ $\mathrm{RT}_{5}$, a modul SMP-D preko $\mathrm{RT}_{4} \mathrm{i} \mathrm{RT}_{6}$. Radi poboljšanja i optimizacije održavanja elektromehaničkih sistema na njihovu magistralu, preko udaljenog terminala $\left(\mathrm{RT}_{9}\right)$, vezan je i upravljački panel održavanja (MDP - Maintenance Data Panel), preko kojeg se obavlja i priključenje test-opreme za kontrolu razmene (protoka) podataka na magistrali. Linije, na slici prikazane strelicama usmerenim ka mehaničkim komponentama, predstavljaju viŠestruke veze SMP-a sa komponentama elektromehanickih sistema aviona. Broj ulaznih signala/broj upravljačkih (pogonskih) signala koje je trebalo integrisati u okviru sistema integrisanog upravljanja elektromehaničkim sistemima može se videti iz sledećeg pregleda:

- motor sa pratecim

sistemima

141 ulazni/33

upravljačka signala,
- gorivni sistem 206 ulaznih/36 upravljačkih signala,

- hidraulični sistem 146 ulaznih/13 - sistemi regulacije uslova u kabini

upravljačkih signala,

- sistemi sekundarnog

napajanja

46 ulaznih/7

59 ulaznih/14

upravljačkih signala, upravljačkih signala, - ostali avionski sistemi .... 34 ulazna/7 upravljačkih signala.

UKUPNO: 632 ulazna/110 upravljačkih signala

U pogledu vrste i tipa ulazno-izlaznih signala u najvećem broju slučajeva pojavljuju se diskretni i analogni signali. Analogni signali obično se odnose na brzine rotacije, linearna i kružna kretanja, temperature, nivoe tečnosti, pritiske i sl. U svim slučajevima u kojima se pojavljuje zatvorena petlja upravljanja pojavljuju se i signali upravljanja (pogona) izvršnim mehanizmima. Distribuirana obrada signala, realizovana pomoću vrlo moćnih mikroprocesora, pruža vrlo velike mogućnosti u pogledu kontrole svih interfejsa i u okviru njih realizovanih ulazno-izlaznih signala. Sa ovako koncipiranim sistemom integrisanog upravljanja elektromehaničkim sistemima, raspoloživost njihovih podataka i pristup njima veći su nego ikada ranije, čime su stvoreni znatno povoljniji uslovi za kontrolu ispravnosti i praćenje stanja svih elektromehaničkih sistema. Mogućnost kontinuiranog prikupljanja i registrovanja podataka, bitnih za praćenje stanja i održavanje elektromehanickih sistema, kao i moguénost povezivanja registratora parametara leta (na magistralu elektromehaničkih sistema) pružaju dodatne mogućnosti u pogledu preventivnog i korektivnog održa- 
vanja $\mathrm{i}$ doprinose još većem značaju integrisanog sistema upravljanja.

Tipiěno korišćeni ulazni signali su razni diskretni, potenciometarski signali raznih sondi (temperaturne, napadnog ugla, ugla klizanja), termistora, centrala pritiska, sinhro-rezolvera i obrtomera (frekventno modulisani). Tipično korišceni izlazni signali su diskretni i upravljacki (pogonski) signali jednosmerne struje, analogni niskonaponski, jakostrujni servo pokretači, slabostrujni servo pokretaci i sl.

Uprošcena arhitektura procesora upravljanja elektromehanickim sistemima (SMP) sa tipičnom organizacijom ulaznih i izlaznih signala (U/I interfejsa), procesora, memorije i interfejsa za magistralu 1553B prikazana je na slici 7. Može se uočiti da se ulazni signali od raznih avionskih senzora, zavisno od njihovih funkcija i prirode, dovode na odgovarajuće interfejse, digitalizuju, obrađuju u centralnoj procesorskoj jedinici (CPU) i konvertuju $\mathrm{u}$ odgovarajuće analogne i diskretne signale, koji se u vidu upravljačkih signala upućuju ka izvršnim mehanizmima (motorima, aktuatorima, elektromagnetnim ventilima i sl.). Izlazni signali, generisani za upravljanje avionskim pumpama, ventilima, aktuatorima i sl. preključuju se (uključuju-isključuju) preko izlaznih relejnih kola, dok se signali za pogon servo motora preključuju preko izlaznih tranzistorskih kola. Digitalizovani podaci elektromehaničkih sistema, preko interfejsa $\left(\mathrm{RT}_{7} \mathrm{i} \mathrm{RT}_{8}\right)$ i magistrala 1553B prenose se do drugih avionskih elektronskih sistema, elektronskih prikazivača i drugih prikazivačkih elemenata u kabini.

Radi eliminacije svih međusobnih uticaja između ulazno-izlaznih kola različitih elektromehaničkih sistema, projektanti sistema poklonili su maksimalnu pažnju razdvajanju električnih strujnih kola. Osim toga, za projektante sistema bilo je neprihvatljivo da u slučaju otkaza
TIPIĆNI ULAZI

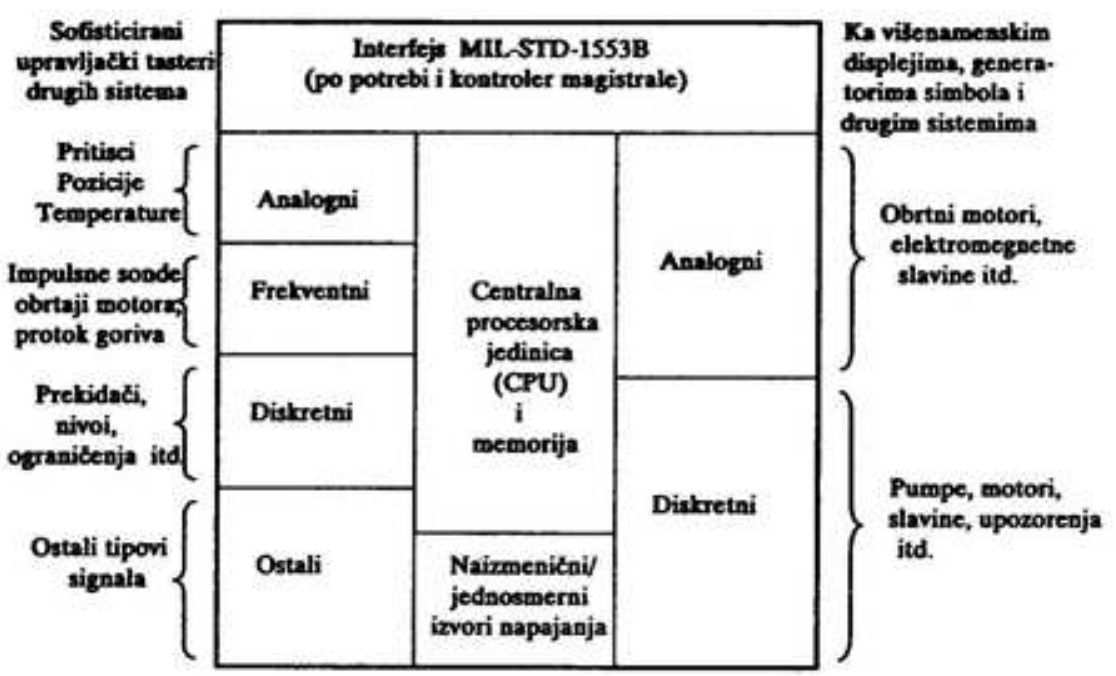

SI. 7 - Uprošcena arhitektura procesora upravljanja elektromehanickkim sistemima (SMP) 
Hardver sistema za gorivo
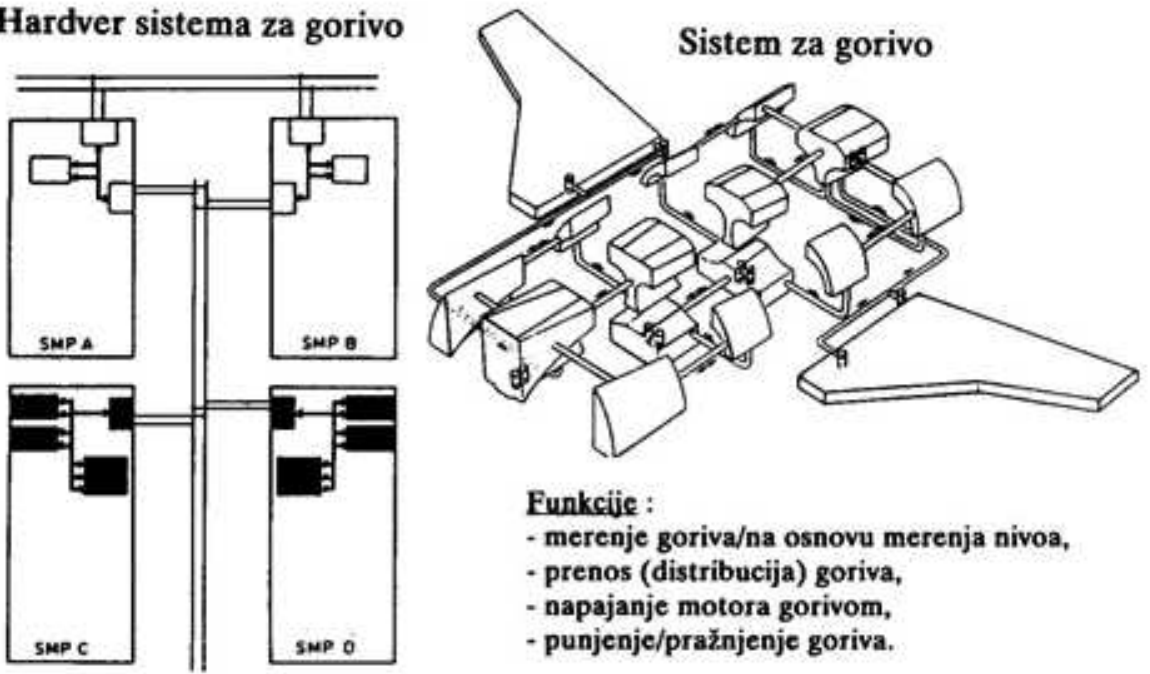

Eunkcije :

- merenje goriva/na osnovu merenja nivoa,

- prenos (distribucija) goriva,

- napajanje motora gorivom,

- punjenje/pražnjenje goriva.

SI. 8 - Sistem za napajanje motora gorivom

jedne, bilo koje interfejsne kartice dođe do otkaza većeg broja elektromehaničkih sistema. Zbog toga je, u toku izrade projekta, maksimalna pažnja poklonjena pronalaženju takvog rešenja koje će obezbediti sto veću pouzdanost rada elektromehaničkih sistema i što veći stepen tolerancije (prevazilaženja) njihovih otkaza. Tom prilikom pošlo se od poznatih činjenica da različiti elektromehanicki sistemi razlicito utiču na bezbednost leta, i da se od njih zahtevaju i različiti nivoi pouzdanosti (tj. različiti nivoi redundovanosti). Jednostavno rešenje sa redundovanjem (dupliranjem, tripliranjem i sl.) svih hardverskih i softverskih modula u ovom slučaju bilo je neprihvatljivo, pošto bi takvo rešenje anuliralo mnoge prethodno navedene i ocekivane prednosti integrisanog sistema upravljanja, tj. umanjilo očekivana smanjenja dimenzija, mase i cene sistema. U takvoj situaciji jedino prihvatljivo i optimalno rešenje bilo je redundovanje ulazno-izlaznih signala $i$ procesiranja (obrade signala), tj. redundovanje interfejsa i procesora i omogućavanje da u slučaju otkaza bilo kojeg procesora ili interfejsa obradu signala preuzme ispravni procesor ili interfejs $i$ to bez ikakve degradacije parametara sistema. Zbog toga su svi procesori upravljanja elektromehaničkim sistemima (SMP) realizovani sa dvoprocesorskom arhitekturom, a svi interfejsi, zavisno od značaja sistema, redundovani (duplirani ili triplirani). Velika raspoloživost ovako realizovanog sistema i otpornost na kritične i katastrofalne otkaze obezbedili su ovom sistemu znatne prednosti u odnosu na sve do sada korišćene konvencionalne elektromehanicke sisteme.

Tipičan primer redundovane (duplirane) hardverske organizacije i povezivanja integrisanog sistema upravljanja napajanjem motora gorivom prikazan je na slici 8. To je hardver koji se odnosi na povezivanje, upravljanje $\mathrm{i}$ prikazivanje sistema za napajanje motora gorivom. $\mathrm{Na}$ istoj slici je i trodimenzionalna (3-D) Šma sistema, a navedene su i sve njegove osnovne funkcije. 


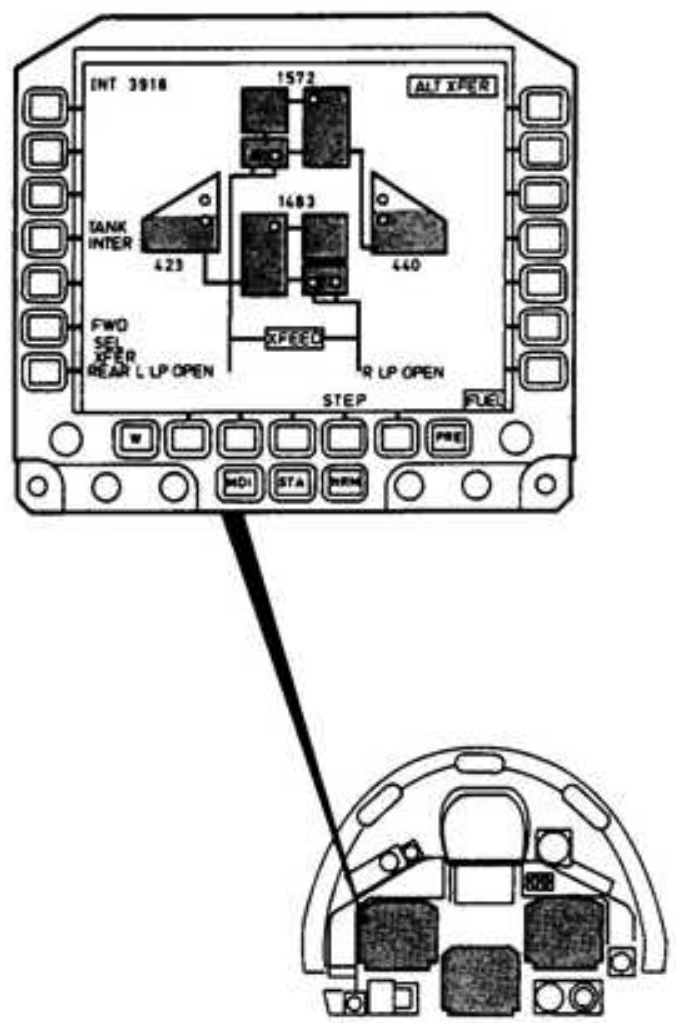

SI. 9-Tipiðno prikazivanje informacija o gorivu
Savremeno koncipirana pilotska kabina i tipičan način i mesto prezentacije informacija o gorivu prikazano je na slici 9. Prikazivanje je realizovano na osnovu podataka prikupljenih i obrađenih u SMP-C i SMP-D, i preko serijske magistrale elektromehaničkih sistema i serijske magistrale avionike, prenetih do generatora simbola, u kojima se generišu simboli koji se prikazuju na višenamenskom elektronskom prikazivaču (po pravilu postavljenom sa leve strane).

Primer redundovane hardverske organizacije i povezivanja integrisanog sistema upravljanja koðenjem i stajnim trapom prikazan je na slici 10 , kao i hardver sistema koji se odnosi na povezivanje, upravljanje i prikazivanje stajnog trapa i njegovog kocenja. Na istoj slici je i trodimenzionalna (3-D) Sema sistema kočenja i stajnog trapa, a navedene su i nejgove osnovne funkcije.

\section{Razvoj softvera}

Pri projektovanju i razvoju softvera korišćen je savremeni pristup koji se

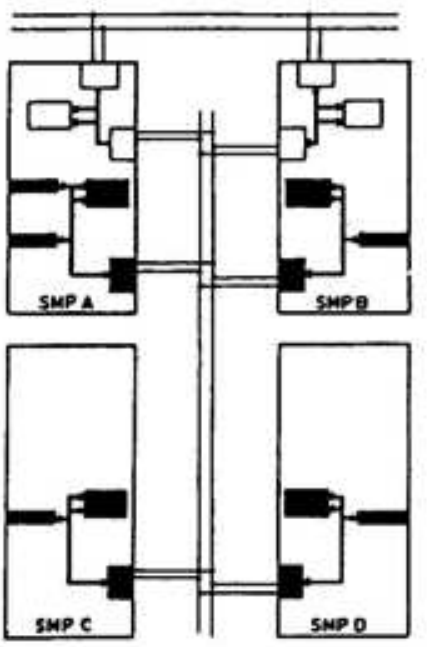

S1. 10 - Sistem kočenja i stajnog trapa 
ogleda u maksimalnoj standardizaciji softvera, tj. razvoju i implementaciji standardnih višestruko upotrebljivih softverskih modula. Korišcen je metod strukturnog modularnog programiranja uz vrlo opsežno testiranje realizovanih modula i programskih paketa. Kontroli (testiranju) softverskih modula posvećena je velika pažnja sve vreme razvoja softvera, ne samo radi postizanja vrlo precizno specificiranih hardverskih i softverskih zahteva već i zbog potrebe obezbeđenja što bolje i preciznije integracije hardvera i softvera i što boljeg i pouzdanijeg definisanja interfejsa između pojedinih sistema. Alati za testiranje sistemskog, aplikativnog i upravljačkog (kontrolnog) softvera koristili su specijalne tehnike kontrole, zasnovane na metodama analize postavljenih zahteva. Ove metode, poznate pod nazivom poluautomatizovane analize funkcionalnih zahteva (SAFRA - Semi-Automated Funcional Requirements Analysis), detaljno su opisane u [1]. Ključne karakteristike metode zasnovane su na isticanju (navođenju) kontrolisanih zahteva (CORE - Controlled Requirement Expression), koji specificiraju sve moguće puteve sistemskih informacija. Razvoj celokupnog softvera sistema vodila je i kontrolisala engleska firma British Aerospace (BAe), koja je izvršila izbor i specificiranje potrebnih hardversko-softverskih alata i projektovala hardversku arhitekturu i softversku strukturu sistema. U razvoju su učestvovali $i$ engleska firma Smiths Industries, italijanska Aeritalia i nemackka Kurt Eichweber.

$\mathrm{Za}$ potrebe sistema integrisanog upravljanja elektromehaničkim sistemima razvijeno je i implementirano oko $400 \mathrm{~K}$ reči softvera. Od toga oko $190 \mathrm{~K}$ reči predstavlja unikatni softver razvijen za potrebe samo ovog sistema i primenljivog samo na njemu. Ostalih $210 \mathrm{~K}$ reci predstavljaju module standardnih višestruko upotrebljivih sistemskih, aplikativnih i kontrolnih softverskih modula. Realizovani softver u potpunosti je dokumentovan prema zahtevima postojećeg standarda za razvoj softvera. U toku realizacije softvera ostvarena je produktivnost od oko 4500 reči godišnje po čoveku. $\mathrm{Na}$ osnovu broja izmena, nacinjenih u svakoj fazi izrade projekta i razvoja softvera, konstatovano je da je ostvaren jedan od prioritetnih ciljeva projekta, t $\mathrm{j}$. da je detekcija velikog broja problema ostvarena u najranijoj fazi projekta i proizvodnje, čime je minimizirana cena razvoja sistema kao i mogućnost programskih prekida (bagova).

Testiranje softvera obavljano je u svakoj fazi njegovog životnog ciklusa (projektovanja i razvoja). Pocetno testiranje obavljano je na centralnoj (host) mašini, a zatim na realnom avionskom hardveru. Tom prilikom najpre su rađeni pojedinačni testovi svakog elektromehaničkog sistema, zatim testovi srodnih grupa sistema i na kraju završni (zajednički) test svih integrisanih sistema. Završni test sistema omogućio je detaljnu proveru integrisanog sistema $\mathrm{i}$ svih njegovih podsistema na zemlji, radi provere zadovoljenja postavljenih zahteva kvaliteta.

Po završetku ispitivanja na zemlji hardver i softver sistema implementiran je na avion, nakon cega su svi integrisani elektromehanicki sistemi funkcionalno provereni u letu.

Detaljan opis softvera, $t j$. softverskih funkcija i modula, za eksperimentalni avionski program (EAP) prikazan je u [2].

\section{Hardver sistema}

Projekat hardvera zasnovan je na određenom broju standardnih elektronskih štampanih ploča (kartica) i modula, 
koji su u okviru integrisanog sistema korišceni na što većem broju mogućih mesta (višestruko upotrebljivi hardverski moduli). $\mathrm{Na}$ osnovu takvog projekta sistema integrisanog upravljanja elektromehaničkim sistemima, realizovan je sa samo 15 štampanih ploča različitog tipa, podeljenih na centralne (procesorske) i U/I štampane ploče. S obzirom na standardizaciju i višestruku upotrebljivost ovih ploča, u okviru celokupnog sistema pojavljuju se ukupno 72 štampane ploče (42 centralne i $30 \mathrm{U} / \mathrm{I}$ ploča).

Korišcenjem projekta višestruko upotrebljivih štampanih ploča, i njihovom primenom na različitim mestima u sistemu, u znatnoj meri se pojednostavljuju poslovi projektovanja, razvoja i testiranja sistema i smanjuje sveukupni rizik uspešnosti realizacije programa. Tako, na primer, kod prototipa sistema integrisanog upravljanja elektromehanickim sistemima, potpuno identična procesorska ploča korišćena je na 8 lokacija ( 8 puta), a U/I ploča diskretnih signala na 11 lokacija (11 puta).

Tipični blok pakovanja elektronike je standardni 3/4 ATR modul, koji sadrži dve elektronske kartice dimenzija $2 \times 3 / 4$ ATR, spojene zajedno u jedinstveni mehanički sklop (modul), sa mogućnošću njegovog postavljanja u linijski zamenljivu jedinicu (LRU) procesora upravljanja elektromehanickkim sistemima (SMP). Bakar nanesen po ivicama i površinama štampanih ploča, zajedno sa mehaničkim sklopom za njihovo pakovanje, obezbeđuje dobro odvođenje toplote ka spoljnim zidovima modula i hlađenje unutrašnjih zidova Štampanih ploča.

Na slici 11 prikazana je jedna od dve linijski zamenljive jedinice (LRU) SMP A ili B ugradene u prednjem delu aviona.

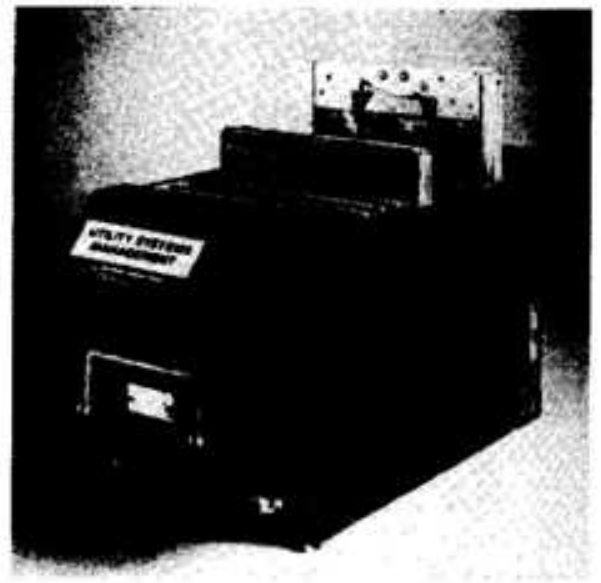

\section{SI. 11 - Izgled prednje strane LRU (SMP A ili B)}

Pristup nekom od 10 njihovih elektronskih modula obezbeđen je sa gornje strane jedinice (LRU). Modul napajanja naizmeničnom energijom lociran je na prednjoj strani jedinice, a modul napajanja jednosmernom energijom na zadnjoj strani. Povezivanje sa avionom (avionskim signalima) izvedeno je preko cetvorostrukog DPX konektora postavljenog na zadnjoj strani jedinice. Konektori magistrale podataka, test-konektori i mrežni konektor postavljeni su sa prednje strane. Moduli linijski zamenljive jedinice hlade se strujanjem spolja uvedenog vazduha preko spoljašnjih površina modula. Masa jedne od ovih linijski zamenljivih jedinica je $12 \mathrm{~kg}$, a primarna snaga disipacije $140 \mathrm{~W}$.

Na slici 12 prikazana je jedna od dve linijski zamenljive jedinice (LRU) SMP C ili D ugrađene u središnji deo aviona. Pristup nekom od 12 njihovih elektronskih modula obezbeđen je sa donje strane jedinice. Izvori napajanja su locirani u gornji deo jedinice, a izvori naizmenične i jednosmerne energije napajanja sa desne i leve strane respektivno. Kao i za prednje jedinice, veze sa avionom (avion- 


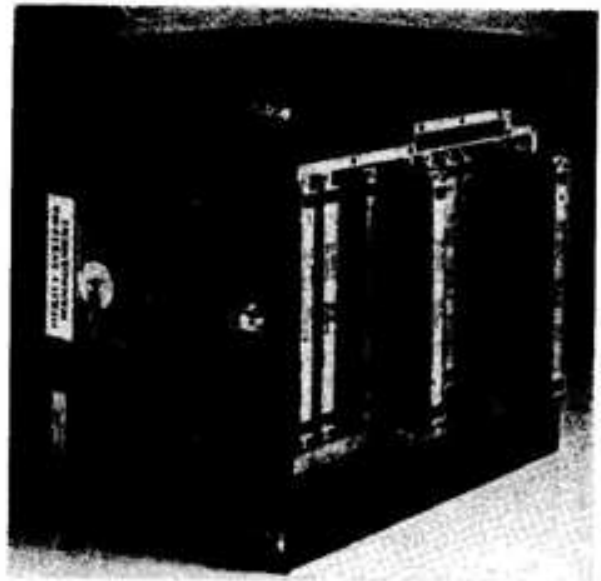

SI. 12 - Izgled zadnje strane LRU (SMP C ili D)

skim signalima) locirane su sa zadnje, a veze sa magistralom podataka, test $i$ mrežnim konektorima sa prednje strane jedinice. Jedinice se hlade strujanjem vazduha, koji se uvodi kroz dva uvodnika sa njihove donje strane, a izbacuje kroz dva otvora sa njihove prednje strane. Masa jedinice je $20 \mathrm{~kg}$, a primarna snaga disipacije $230 \mathrm{~W}$.

\section{Zaključak}

Smanjenje broja posebno (linijski) zamenljivih jedinica (LRU), korišcenih za upravljanje elektromehaničkim sistemima, dovelo je do znatnog smanjenja ukupnih dimenzija i mase sistema. Korišcenje savremenih tehnologija mikroelektronskih kola, mikroprocesora, memorija vrlo velike gustine pakovanja i magistrala podataka omogućilo je znatno poboljకanje elektronike i pouzdanosti sistema. Realizovano hardversko-softversko rešenje sistema integrisanog upravljanja elektromehaničkim sistemima, pruža i značajna poboljšanja u pogledu prevazilaženja (tolerancije) otkaza i pristupa i mani- pulacije podacima elektromehaničkih sistema. Osim toga, mogućnosti kontinualnog praćenja stanja svih integrisanih podsistema i daljeg prosirenja sistema znatno su povećane.

Osnovna poboljšanja ostvarena realizacijom sistema integrisanog upravljanja elektromehaničkim sistemima, za tipične savremene visokoperformansne borbene avione mogu se sumirati na sledeći način: ukupna masa sistema $\mathrm{i}$ operativna cena sistema smanjeni su za preko $50 \%$, dok je raspoloživost sistema povećana preko 8 puta.

Osnovni ključ dobro realizovanog softvera i velike produktivnosti njegove realizacije nalazi se u primeni vrlo strogih metoda softverske kontrole i upravljanja. Kao vrlo moćan alat, ne samo za projektovanje već i za što raniju detekciju greŠaka, korišćen je CORE metod, koji je pokazao veliku efikasnost u pogledu pružanja pomoći timovima inženjera u brzom lociranju softverskih problema i njihovom prevazilaženju.

Modularni pristup realizacije hardvera, zasnovan na standardnim vǐ̌estruko upotrebljivim modulima, doveo je do vrlo velikih poboljšanja sistema. Maksimalna univerzalnost i fleksibilnost korišcenih setova test-opreme omogucili su blagovremenu detekciju hardverskih gresaka radi njihovog prevazilaženja u najranijim fazama projektovanja i razvoja sistema.

\section{Literatura:}

[1] Ward. A. O.: Consistent Approach to the Development of System Requirements and Softrare Design, AGARD Technical Airbone Distributed Computing Networks, fune 1981.

[2] Seabridge, A. G.: Smith, R. A. C.: Production of Real Time Software for an Airbone Application in the EAP, maj 1989.

[3] Mior, I.; Seabridge A. G.: Worton, Management of Utility Systems in the Experimental Aircraft Programme, oktobar 1989. 